\title{
EBPTの実践に向けて
}

\author{
For the Practice of EBPT
}

\section{木村 貞治1)}

TEIJI KIMURA, RPT, $\mathrm{PhD}^{1)}$

1) Department of Physical Therapy, School of Health Sciences, School of Medicine, Shinshu University: 3-1-1 Asahi, Matsumoto, Nagano 390-8621, Japan.

Rigakuryoho Kagaku 22(1): 19-26, 2007. Submitted Dec. 21, 2006.

ABSTRACT: The validity of clinical diagnosis for planning of intervention policy in physical therapy may influence the intervention effects itself. Therefore, it is important to promote a conversion conceptual framework from conventional empirical rule-based physical therapy to evidence-based physical therapy (EBPT). To put EBPT into practice, not only evidence of experimental proof by clinical research but patients' intention and values, and total clinical diagnosis which integrates physical therapists' specialized knowledge and skills are important.

Key words: EBPT, clinical research, evidence datebase

要旨 : 理学療法における介入方針を立案するための臨床判断の妥当性は, 理学療法の介入効果そのものを左右する可 能性がある。したがって, 従来の経験則基盤型の理学療法から, 科学的根拠に基づく理学療法 (Evidence-based Physical Therapy, EBPT）へと概念的枠組みの変換を推進していくことが重要となっている。EBPTを実践していくためには, 臨床研究による実証報告としてのエビデンスだけでなく, 患者の意向や価值観, そして, 理学療法士の専門的知識や 技能を統合した総合的な臨床判断が重要となる。

キーワード : EBPT, 臨床研究, エビデンスデータベース

1) 信州大学 医学部保健学科理学療法学専攻 : 長野県松本市旭3-1-1（テ390-8621）

受付日 2006年12月21日 


\section{I. はじめに}

理学療法の対象者に適切な介入を実施するためには, 対象者の状況に即した適切な臨床判断 (clinical decision making）を行うことが重要となる。そして, 適切な臨床 判断を行うためには, 対象者の年齢, 疾病特性, 障害特 性, 環境因子，リスク因子，そして，ニーズなど，多様 な因子を考慮した総合的な情報処理を遂行することが 必要となる。このような多様かつ階層的なマトリックス で構成されている臨床問題に対して, どのような理学療 法をどのような順序で行えばよいのかという臨床判断 のための思考過程は非常に複雑となる。

従来, わが国の理学療法における臨床判断は, 欧米か ら導入された治療概念, 病態生理学的な知見, そして, 個々の理学療法士の経験則や慣習などに基づいて行わ れてきた。しかし，個人の経験則などに基づく臨床判断 だけでは, 偶然性や思いこみなど様々なバイアスの影響 を受けることによって, 個々の担当患者にとっての最適 の意思決定とならない場合が生じる可能性がある。

医療現場におけるこのようなバイアスの影響を受け やすい不確実な状況下での臨床判断を科学的な根拠に 基づいて実施するための行動指針として，「科学的根拠 に基づく医療（Evidence-based Medicine，EBM）」の概念 が，1991年にGuyattら 1)によって提唱された。

そして，このようなEBMの潮流を受けて，わが国の 理学療法分野においても, 従来の経験則基盤型の理学療 法から,「科学的な根拠に基づく理学療法 (Evidence-based Physical Therapy, EBPT)」へ, パラダイムシフトを推進 するための取り組みが進められてきた。

しかし，EBPTの理解の程度や実践状況に関しては, 個々の理学療法士によって, そして, 施設によって少な からず温度差があるように思われる。また, EBPTを臨 床現場で実践寸る上で活用できる理学療法分野のエビ デンスがまだ少ないことも大きな課題の1つとしてあげ られる。

一方, エビデンスを構築していく上では, 疾患別の評 価フォーマットの標準化が不十分であること, 理学療法 分野においてはランダム化比較試験 (randomized controlled trial， RCT）の実施が困難な場合が多いこと， 理学療法における介入変数が多様であるとともに, アウ トカムが多様かつ階層的であるため同一の研究テーマ に関するエビデンスが構築しにくいこと,チーム医療の 中で実施している理学療法としては, 単独の介入効果の 抽出には限界があることなど, いくつかの課題があるの も事実であろう。
したがって, 理学療法における臨床判断をEBPTの概 念に基づいて展開していくためには, EBPTの理念，方 法, そして, 課題や限界などを正しく理解した上で, 実 用的にエビデンスを参照した臨床判断を行うとともに, わが国の文化や生活様式に即した理学療法分野のエビ デンスの蓄積と公表を組織的に展開していくことが重 要な課題であると考える。

本稿では, このような状況を鑑み, 今後, EBPTを推 進するための具体的な方略であるエビデンスを「使う」, 「作る」，「伝える」という取り組みについて概説してみ たい。

\section{EBPTの概要}

EBMとは, 「入手可能で最良の科学的根拠を把握した 上で, 個々の患者に特有の臨床状況と価值観に配慮した 医療を行うための一連の行動指針」 ${ }^{2)}$, あるいは, 「個々 の患者の臨床問題に対して, (1)患者の意向, (2)医師の専 門技能, (3)臨床研究による実証報告を統合して判断を下 し, 最善の医療を提供する行動様式」3などと定義され ている。そして，EBMのキー概念であるエビデンスと は, 「臨床研究による実証報告」3), または, 「臨床判断 に客観的な根拠を与えるための一般的情報」4) と定義さ れている。このようなEBMの概念は, わが国における 様々な医療の分野における成書, 学術雑誌, 学会などで 取り上げられ, 実際の臨床現場においてその実践が展開 されてきている。

そして, 近年ではEBMの潮流を受けて, わが国の理 学療法においても,「科学的根拠に基づく理学療法 (EBPT)」の実践に向けての取り組みが行われてきてい る。

EBPTの概念を上述のようなEBMの定義を参考にして 定義すると,「個々の患者の臨床問題に対して, (1)患者の 意向や価值観, (2)理学療法士の専門的知識と技能, (3)臨 床研究による実証報告としての科学的根拠を統合して臨 床判断を行うことによって, 最善の理学療法を提供する ための一連の行動様式」と位置づけることができよう。

このようなEBPTの普及と実践に向けて, わが国の理 学療法分野における学会, 研修会, そして, 理学療法関 連雑誌等において, EBPTの概念や方法論についての紹 介が行われてきている5-12)。

日本理学療法学術大会では, 第35回学会 (2000年) に おいて「理学療法の効果判定」, 第38回学会 (2003年) に おいて「科学的根拠に基づく理学療法」がそれぞれテー マとして揭げられた。とくに第38回学会においては, 
EBPTの実践を目指して, EBPTの概念から具体的な実践 方法までの一連の情報が, 大会長基調講演, 特別講演, シンポジウム, ワークショップを通して示された。これ らのうち特別講演においては, 理学療法関連のエビデン スデータベースであるPEDro (Physiotherapy Evidence Database)を運営しているCEBP (Center for Evidence-Based Physiotherapy）のメンバーであるシドニー大学理学療法 学部のRobert Herbert氏から, EBPTの実践に向けての具 体的な方法論についての紹介が行われた ${ }^{13)}$ 。

また, 社団法人日本理学療法士協会においては, 2005 年にEBPTプロジェクト特別委員会が設置され, わが国 におけるEBPTの実践を支援するための組織的な取り組 みが始動した。

EBPTに関するこのような組織的な取り組みや学術的 な情報を活用して, 従来の経験則基盤型の臨床判断か ら, (1)患者の意向や価值観, (2)理学療法士の専門的知識 と技能, (3)入手可能で最良の臨床研究による実証報告と しての科学的根拠を統合した臨床判断へと, 概念的枠組 みの変換を推進していくことが, わが国における理学療 法の重要な課題となっている。

\section{EBPTの実践に向けて}

EBPTを臨床の現場で具体的に実践していくためには， 個々の担当患者における臨床的な疑問に関するエビデ ンスを効率よく検索, 収集し, ヒットしたエビデンスの 内容を吟味して, 担当患者への介入に関する臨床判断を 行うという過程である「エビデンスを使う」という取り 組みが基本となる。

しかし, 理学療法分野のエビデンスが決して十分で はない現状から, 質の高い臨床研究の結果を組織的に収 集, 統合することによって「エビデンスを作る」という 取り組みが重要となる。

そして, 疾患や障害の特性に応じた介入効果に関す るエビデンスが構築されれば, それらを公表することに よって「エビデンスを伝える」という活動が必要になる。

したがって, 今後EBPTを推進していくためには, 臨 床場面における担当患者の臨床的疑問に対する臨床判 断の根拠の1つとして「エビデンスを使う」という行動 が実用的に実践できるように, 多様な理学療法の状況に 即した「エビデンスを作る」という取り組みと, それら の「エビデンスを伝える」という取り組みが，三位一体 となって有機的に展開されることが重要となる。

以下に, EBPT実践に向けての基本的な方略について 整理してみたい。

\section{表1 EBPTの進め方}

ステップ 1 :臨床上の疑問点の抽出と定式化

ステップ 2 : 臨床上の疑問点に関する情報の検索

ステップ 3 :得られた情報の批判的吟味

ステップ 4:得られた情報の患者への適用の検討

ステップ 5 :介入結果の評価

1. エビデンスを「使う」

エビデンスを使うための具体的な流れは，表1に示す とおり, (1)臨床上の疑問点の抽出と定式化, (2)臨床上の 疑問点に関する情報の検索, (3)得られた情報の批判的吟 味, (4)得られた情報の患者への適用の検討, (5)介入結果 の評価という5つのステップとなる。

ステップ1: 臨床上の疑問点の抽出と定式化

EBPTを実践するための第一歩は，日々の臨床活動に おける様々な疑問を抽出し, 調べやすい形に整理するこ とである。臨床的な疑問を明確にするためには, 疑問に 対して答えやすい形にするために, “PICO”というフォー マットに整理することがポイントとなる。PICOとは，P (Patient)：どのような患者に, I (Intervention)：どのよ うな介入を行った場合, C (Comparison)：何と比較し て, O (Outcome) : どのような結果になるか, というよ うに疑問点を定式化するためのフォーマットのことで ある。このようなPICOによる疑問点の定式化に基づい て，具体的な文献検索を展開することになる。

理学療法におけるPICOの例としては, P : 慢性的な腰 痛を呈する患者に, I : 超音波療法を実施した場合と, $\mathrm{C}$ : 電気刺激療法を実施した場合とでは, $\mathrm{O}$ ：どちらの 治療法の方が疼痛軽減効果が高いか? などのように, で きるだけ具体的な構成要素に整理して定式化すること がポイントとなる。

このような疑問点を抽出するためには, 日々の臨床 活動で感じた疑問点をカルテに明記するとともに, それ らを疑問点リストとしてエクセルのワークシートなど にリストアップしていくことが有用である。

ステップ2 : 臨床上の疑問点に関する情報の検索 $\mathrm{PICO}$ によって疑問点が整理されれば，次のステップ として, PICOに関連した文献を検索・収集する作業に 進む。

文献情報には一次情報（primary information）と二次情 報（secondary information）がある。一次情報とは，専門 誌や学会誌・協会誌に掲載されている独創的な学術研究 
の成果を理論的にまとめた原著論文のことである。ま た, 二次情報とは, 複数の原著論文を要約して1つにま とめたもので, メタ分析 (meta-analysis) や系統的総説 (systematic review), そして, ガイドラインなどがこれに あたる。

系統的総説とは, (1)研究テーマの設定, (2)テーマに関 連する一次情報の収集, (3)各一次情報の批判的吟味 (critical appraisal), (4)結果の解釈, (5)編集と更新という 作業を通して, 一次情報を総合的に取りまとめたもので ある。また, メタ分析とは, 同様に複数の一次情報を収 集し, 各一次情報の結果をオッズ比などを指標として定 量的（統計学的）手法に基づいて統合したものである。

多忙な臨床現場で効率よくEBPTを実践していくため には, PICOに基づいて,まず, これらの二次情報を検 索することである。何故ならば，二次情報はEBMの手順 に精通したグループが, 一次情報を網羅的に検索・収集 し, 最新, 最良のエビデンスとしてまとめ, 世界中に発 信してくれているからである14)。

これらの二次情報の中でも, とくに, 患者を介入群と 対照群に無作為に割り付けし, 両群の比較に基づいて介 入効果を検証したランダム化比較試験（RCT）の結果を 統計学的手法を用いて総合的に分析したメタ分析の結 果に基づいて取りまとめられた系統的総説は, 臨床疫学 的な指標としての有用性が高い（表2）。

二次情報を検索するためには, 理学療法関連のデー タベースであるPEDro（Physiotherapy Evidence Database） (http://www.pedro.fhs.usyd.edu.au/) や, イギリスで発足し た治療・予防に関する医療の評価プロジェクトであるコ クラン共同計画 (Cochrane Collaboration, http://www. cochrane.org/index.htm）におけるCochrane Library（http:// www.cochrane.org/reviews/clibintro.htm) などのデータベー スを活用することが有用である。

また，設定したPICOに関連した二次情報が入手でき ない場合には, 一次情報である原著論文を検索すること になる。

このようなエビデンスの検索のためには, 米国国立
医学図書館（National Library of Medicine，NLM）が提供 する医学文献データベースMEDLINE（Medical Literature Analysis and Retrieval System On-Line）の無料検索サービ スであるPubMed (http://www.ncbi.nlm.nih.gov/entrez/query. fcgi?DB=pubmed) やEMBASE (http://www.embase. com/) な どのデータベースを活用することになる。

しかし，原著論文を検索する場合，検索条件によって は膨大な数の論文がヒットするため, 多忙な臨床業務の 合間でこれらの一次情報の内容を把握することは効率 が悪い。そこで, PubMedでキーワードを入力するクエ リーボックスにPICOに関連したキーワードを入力した 結果, ヒットした文献が多すぎる場合には, クエリー ボックスのすぐ下にあるフィーチャーズバーの“Limits” の機能を利用して, 文献の言語や文献のタイプ, そし て，出版年などで絞り込むと効率がいい。

また, 逆にヒットした文献が少ない場合には，すぐに 諦めずに, クエリーボックスの左下にあるサイドバーの 中央付近にあるMeSH Databaseを活用して, MEDLINEで 使われているキーワードを検索することが大切である。 “MeSH”とは, Medical Subject Headingsの略で, NLMが 医学用語をできるだけ統一して使用するために作成し た見出し語すなわちシソーラスのことである15)。

ステップ3:得られた情報の批判的吟味 (critical appraisal) 系統的総説などの二次情報がヒットした場合には, 専 門家によって内的妥当性が吟味されているため, 自分が 設定したPICOと二次情報の結果との整合性の程度を確 認した上で，ステップ4の患者への適用について検討す ることになる12)。

また，PICOで検索しヒットした文献が一次情報の場 合には, その文献の内容を妥当性や信頼性の面から批判 的に吟味する必要がある。批判的に吟味する場合のポイ ントは, 表 2 に示すような研究デザインのレベルの評価 を行うとともに，表3や次に示すような観点から論文の 内的妥当性を検討することである。具体的には, 研究の デザインとして, 理学療法プログラムへの割付が無作為

\begin{tabular}{ll} 
表2 & エビデンスのレベル(文献2を一部改変) \\
\hline $\mathrm{Ia}$ & ランダム化比較試験 $(\mathrm{RCT})$ のメタ分析による \\
$\mathrm{Ib}$ & 少なくとも 1 つのランダム化比較試験 $(\mathrm{RCT})$ による \\
$\mathrm{IIa}$ & 少なくとも 1 つのよくデザインされた非ランダム化比較試験による \\
$\mathrm{IIb}$ & 少なくとも 1 つの他のタイプのよくデザインされた準実験的研究による \\
$\mathrm{III}$ & 比較研究や相関研究, 症例対照研究など,よくデザインされた非実験的記述的研究による \\
$\mathrm{IV}$ & 専門家委員会の報告や意見, あるいは権威者の臨床経験 \\
\hline
\end{tabular}


表3 EBPT実践用ワークシート（文献12を一部改変）

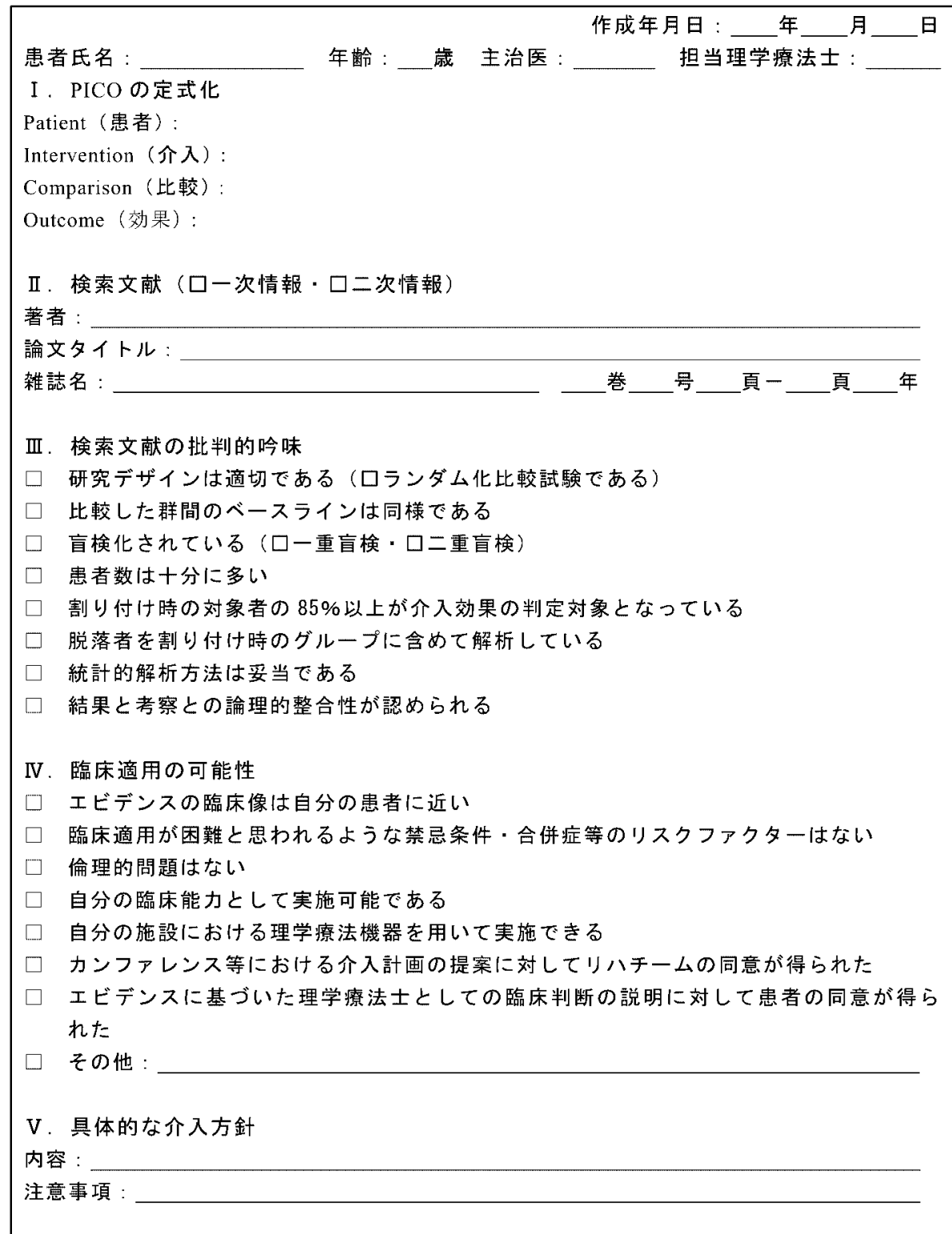

で行われたか? 患者数は十分に多いか? フォローアップ は十分に長く行われたか? 臨床的アウトカムが評価指標 (エンドポイント) とされているか? 統計学的解析方法 は妥当か? 理学療法の介入によるマイナスの影響につい ても報告されているか?などのチェックポイントがあげ られる12)。

一次情報の批判的吟味において重要な点は, 闇雲に 論文の質的な問題点を列挙するのではなく, 担当患者に 関する臨床上の疑問・問題点を解決する上で, その論文 が根拠になり得るかどうかを検討することである12)。
また, 表3に示すようなワークシートを各自が作成し, それらをテーマ別に分類したファイルに一元管理する ことにより, 複数のスタッフが臨床現場で効率よく EBPT を実践していくことが可能になる。ただし, 系統的総説 の内容には賞味期限があるため, 定期的に新しい内容に 更新していくことが重要である。

ステップ4: 得られた情報の患者への適用の検討

ステップ4では, ステップ3で批判的に吟味したエビデ ンスの結果を実際の担当患者に適用するかどうかにつ 
いて検討する。

この段階で重要な点は, 論文の結果（best research evidence）だけでなく，患者の価值観（patient value）（意 欲, 目標等) や, 理学療法士の専門的知識と技能 (clinical expertise）などと併せて総合的に介入方針を検討してい

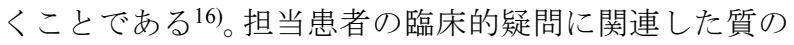
高いエビデンスを入手できたとしても, 患者の意向や価 值観と合わなかった場合や, 治療環境などの面から実践 が難しいと思われた場合には他の選択肢について検討 しなければならない11,12)。

そして, 担当患者の臨床的疑問に関連したエビデン スの結果を包含した理学療法士としての総合的な臨床 判断の根拠と具体的な介入方針を患者や家族に対して 分かりやすく, そして, 丁寧に説明することによって患 者自身に納得していただいた上で, 積極的に理学療法に 取り組むという姿勢をもっていただくことが重要であ る $^{12)}$ 。

また, EBMやEBPTに対する誤解の1つとして, 臨床疫 学的な研究結果の数值に偏重した判断であるという指 摘があげられるが，決してそうではなく，上述のように 患者の意向や価值観を丁寧に考慮した上で総合的な臨 床判断を下すことによって, できるだけ質の高い医療を 提供寸るという患者中心型医療としての具体的な方略 であることをきちんと理解することが重要である17)。

斎藤到は，EBMについて，「何らかの疾患をもった患 者一般について, 何らかの一般的判断を行うこと」と誤 解されることが多いことを指摘した上で,「エビデンス とは臨床判断に利用される一般的情報であり, EBM は, エビデンスを有効に利用することで個々の患者の最 大幸福を目指寸診療実践である。EBMとエビデンスの 概念を混同してはならない。」と述べている。

\section{ステップ5: 介入結果の評価}

ステップ4で，エビデンスの結果も踏まえた総合的な 臨床判断とインフォームドコンセントに基づいて具体 的な介入が実施されれば, その短期的, 長期的効果につ いて自己評価することが重要となる。

どのような臨床問題に対して, 何を根拠として, どの ような介入方針に関する臨床判断を行い, その結果, ど のように臨床問題が変化したのか, という一連の情報を 明確な操作的定義のもとにデータベースとして蓄積し ていくことが, この後に述べる「エビデンスを作る」と いう重要な取り組みにつながっていくことになる。
2. エビデンスを「作る」，そして，「伝える」

これまで述べてきたような二次情報を臨床現場で活 用していく上で, 定式化したPICOの内容によっては, 関 連するエビデンスがヒットしない場合もある。とくに, わが国の理学療法分野においては, 一次情報としての原 著は数多く公表されているが, それらの一次情報の内容 を吟味した上で, 系統的にとりまとめた二次情報として のエビデンスは, 非常に少ないというのが現状である。

したがって, 日本の文化, 制度の中で行われ, 日本語 で報告された理学療法関連の臨床研究の結果である一 次情報を取りまとめたメタ分析や系統的総説などの二 次情報を構築し，それらを公表していくことが，わが国 における理学療法分野の大きな課題となっている。

このような状況を鑑みて, 2005年に社団法人日本理学 療法士協会にEBPTを組織的に推進するためのプロジェ クトとして, EBPTプロジェクト特別委員会が設置され た。筆者も同委員会のメンバーであることから，わが国 の理学療法分野のエビデンスを「作り」,「伝える」こと によって, 臨床場面において実用的にエビデンスを「使 う」ということを支援することを目的としたエビデンス データベースシステムの概要について以下に紹介寸る。

EBPTプロジェクト委員会では, わが国におけるEBPT の実践の普及を推進することを目的として，インター ネットを利用したエビデンスデータベースシステムで あるJAPTED (Japan Physical Therapy Evidence Database)を 構築してきた。JAPTEDは, 図1に示すとおり, 全国の理 学療法士と, 専門領域研究部会など協会組織側のワーキ ンググループとの間において, エビデンスの橋渡しを支 援するためのエビデンスデータベースシステムである。

JAPTEDの理念は，多施設間共同研究などによる介入 研究の結果に基づくエビデンスの構築 (Data Working) と, すでに論文として報告されている原著 (一次情報) の結果を取りまとめたエビデンスの構築 (Paper Working) によってエビデンスを「作り」，それを「伝える」こと によって, 全国の理学療法士が担当患者に対する臨床判 断を行う際にエビデンスを実践的に「使う」ことができ るよう支援することである。

JAPTEDの機能は, EBPTの実践に必要な次のような3 つのプロセスを支援することを目的としている。

(1)エビデンスを作る

各専門領域研究会など協会組織のワーキンググルー プが中心となって, 疾患別, 介入内容別の介入効果に関 する多施設間共同研究を推進し,それらの結果をJAPTED に送信してもらうことがエビデンス作りの第一段階と 


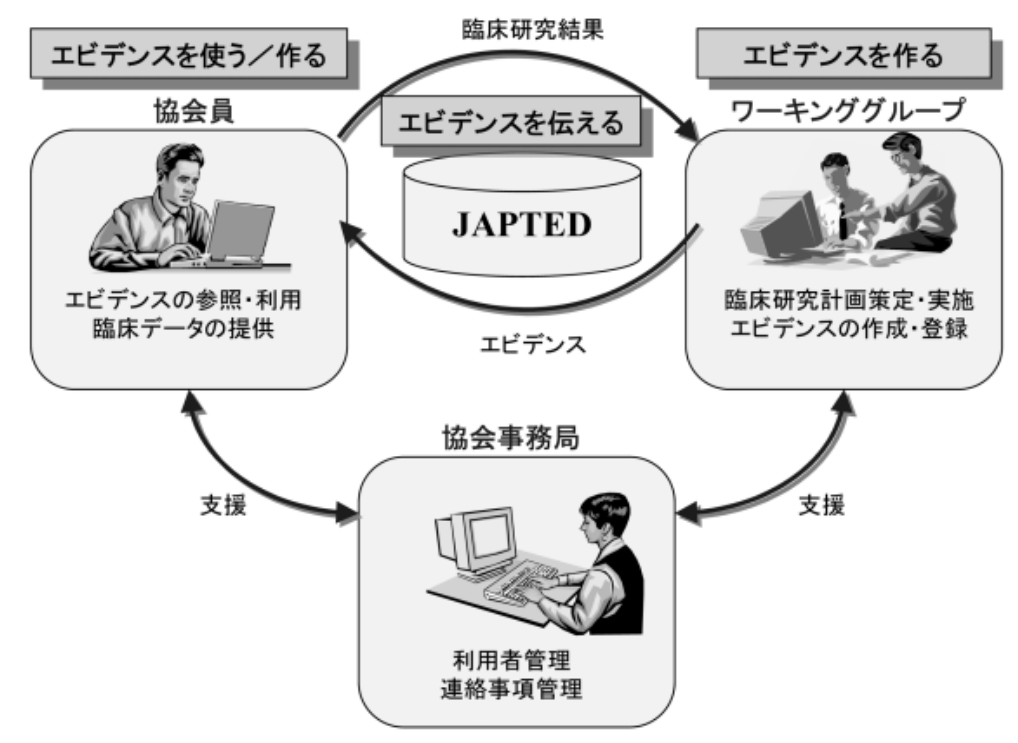

図1 社団法人日本理学療法士協会 EBPT プロジェクト特別委員会で構築中 である理学療法分野のエビデンスデータベースであるJAPTED（Japan Physical Therapy Evidence Database）の概念図

なる。

しかし，この段階において, 領域別に研究テーマとし て掲げた疾患に関する “評価項目”や“評価方法”が統 一されていなければ,いくら多くのデータを集めても意 味のあるデー夕にはならない。そこで, 主要疾患に関す る標準化された評価フォーマット (Clinical Evaluation Format， CEF）の構築と, 評価方法の統一のための技術 研修会を開催した上で多施設間共同研究を展開し, 同一 疾患群に対する介入内容別の効果の大きさを比較する ことが重要な取り組みとなる。

そして, 次の段階としては, ワーキンググループが中 心となって，JAPTEDを用いて収集した複数の多施設間 共同研究の成果をJAPTEDのメ夕分析機能を用いて統計 学的に分析, 統合し, その結果を系統的総説としてとり まとめることによって,「エビデンスを作る」ことになる。

また, JAPTEDは, 上述のとおり, このような臨床デー 夕に基づくエビデンスの構築（Data Working）だけでな く,論文として公表されている一次情報の結果を系統的 総説にとりまとめることによるエビデンスの構築 (Paper Working）を支援する機能も有している。

(2) エビデンスを伝える

ワーキンググループが中心となって構築した Data WorkingやPaper Workingに基づくエビデンスをJAPTEDに アップすることによって, 全国の理学療法士に対して
「エビデンスを伝える」ことが可能になる。

EBPTの実践においては，多忙な臨床業務の中ででき るだけ効率よくエビデンスを検索, 収集することがポイ ントとなる。したがって, 全国の理学療法士が, PEDro やPubMedを利用した英文のエビデンスの検索, 収集と 併せて，JAPTEDを利用することによって，日本語のエ ビデンスを臨床判断の根拠の1つとして活用できるよう に「エビデンスを伝える」ことが重要な取り組みとなる。

(3) エビデンスを使う

JAPTEDを利用した組織的なエビデンスの構築と公表 によって, 全国の理学療法士が, 担当患者に関する臨床 判断を行う際に, 日本で行われた質の高い理学療法の臨 床結果に基づいたエビデンスを活用する，すなわち「エ ビデンスを使う」という活動が促進される。

しかし, 理学療法が対象とする疾患, 障害と介入内容 の多様性から勘案して, 層別化された多様な臨床象に対 する臨床判断のためのエビデンスを構築していくため には, 協会組織におけるワーキンググループの精力的か つ継続的な活動と, 全国の理学療法士の継続的な協力が 必須の条件となる。

おわりに

理学療法士の臨床活動は, 臨床判断の連続である。患 者の表情や言動に応じた接遇の仕方に関する判断, 評価 方法に関する判断, 臨床推論に基づく障害特性に関する 
判断, 介入方針に関する判断など, 多様な臨床判断を限 られた時間の中で遂行していかなくてはならない。

これらの臨床判断のうち介入方針に関する判断の妥 当性は, 担当患者に対する理学療法の効果を左右するこ とになる。したがって, 患者にとって最良の選択となる ように, 理学療法士自身が自己の臨床判断の妥当性その ものを謙虚に吟味することが重要である。

そのための具体的な方略としてEBPTの実践がある。 今後わが国においてEBPTを実用的に展開していくため には，患者に対する最良の介入方針を検討するために 「エビデンスを使う」ことができるよう，「エビデンスを 作る」,「エビデンスを伝える」という組織的な取り組み が重要となる。そして, そのような組織的な取り組みの 1つとして, 本稿で紹介したエビデンスデータベースで あるJAPTEDの活用があげられる。

全国の理学療法士が担当している患者やその家族の 方々が, できるだけ健康で, そして, 少しでも自分らし い生活を送れるよう質の高い理学療法を提供していく ためには, 多くの理学療法士の真摰な臨床活動と併せ て,お互いが共有できる質の高いエビデンスを構築して いくための地道な努力が必要不可欠となる。そのような 弛まない組織的な活動によってJAPTEDからエビデンス が発信され, それらのエビデンスが多くの理学療法士の 臨床判断の一助を担っていくことを期待したい。

\section{引用文献}

1) Guyatt GH: Evidence-based Medicine. ACP Journal Club, 1991,

\section{March/April, A16.}

2) 福井次矢 (編) : EBM実践ガイド. 医学書院, 東京, 2000.

3) 能登 洋: EBMの正しい理解と実践. 羊土社, 東京, 2003.

4) 斎藤清二: EBMの目的とその誤解について. 理学療法, 2006, 23(11): 1535-1541.

5) 中澤住夫 : 理学療法の臨床研究とEBPTの課題. 理学療法学, 2003, 30(8): 440-444.

6) 丸山仁司 : 理学療法におけるEBMの実際. 理学療法学, 2003, 30(8): 445-446.

7) 伊橋光二: 科学的根拠に基づく理学療法と研究方法論一根拠 を創るには一. 理学療法学, 2003,30(8): 447-451.

8) 大峯三郎：理学療法におけるEBMの実際一臨床分野から一. 理学療法学, 2003, 30(8): 452-454.

9) 荻島久裕：理学療法におけるEBMの実際一教育分野から一. 理学療法学, 2003, 30(8): 455-458.

10) 中澤住夫 : EBMからEBPTへ. 理学療法, 2001, 18(11): 10321035.

11) 木村貞治 : EBPTの実践. 理学療法学, 2004, 31(4): 263-266.

12) 木村貞治 : 科学的根拠に基づく理学療法モデル. 理学療法 ジャーナル, 2004, 38(5): 358-367.

13) Herbert RD, Sherrington C, Moseley AM, et al.: Evidence-based physical therapy. 理学療法学, 2003, 30(8): 431-439.

14) 福井次矢 : EBMの基礎知識. 理学療法, 2001, 18(11): 10251031.

15) 阿部信一, 奥出麻里 : 図解PubMed の使い方. 日本医学図書 館協会, 東京, 2003.

16) Sackett DL, Straus SE, Richardson WS, et al.: Evidence-based Medicine, How to Practice and Teach EBM, 2nd ed. Churchill Livingston, London, 2000.

17) Stewart M, Brown JB: Patient-centredness in medicine. Evidencebased patient choice: inevitable or impossible? Oxford University Press, Oxford, 2001, pp97-117. 